\title{
THE INCREASE IN PLASMA PROGESTERONE LEVELS IN THE PREGNANT GUINEA-PIG AND ITS POSSIBLE SIGNIFICANCE
}

\author{
R. B. HEAP AND R. DEANESLY \\ A.R.C. Institute of Animal Physiology, Babraham, Cambridge
}

(Received 23rd Fune 1967)

Plasma progesterone concentrations in the pregnant guinea-pig are greater than in many species (Heap \& Deanesly, 1966; Heap, Perry \& Rowlands, 1967) and far higher than those found in the normal cycle (Table 1). The present experiments were intended to compare the effects of subcutaneous progesterone tablets on plasma progesterone levels after ovariectomy with those in normal, non-pregnant and pregnant females.

The ovaries are essential for pregnancy in most guinea-pigs between about Days 14 and 28 (Deanesly, 1963) but from about Day 28 pregnancy will continue normally without exogenous hormones owing to the production of placental progesterone. In this study it was decided to use females in the 1st month of pregnancy when the actual production of progesterone by the placenta is far less than that of the ovary and is well below that reached in later stages (Heap \& Deanesly, 1966).

Guinea-pig pregnancies were dated from Day 0, the day of the vaginal plug. Ovariectomies and insertion of compressed progesterone tablets were done under ether anaesthesia in the 1st week after ovulation. Disc-shaped tablets of solid progesterone (about $40 \mathrm{mg}$ each) were weighed and placed subcutaneously. Pregnant, ovariectomized females were autopsied by Day 30 and non-pregnant ones 19 to 47 days after tablet implantation. Tablets were cleaned, dried and re-weighed to the nearest milligram, and the total amount absorbed calculated, and thence the average daily rate of absorption. This varied according to the quantity implanted and the number of tablets, but was apparently not affected by the reproductive condition of the animals (Table 1). Blood for progesterone assay was withdrawn by cardiac puncture under ether and 'Avertin' (tribromoethanol) anaesthesia. Foetuses and placentae were examined and uterus and vagina removed for histological examination. The progesterone assay was as previously described (Heap, 1964; Heap \& Deanesly, 1966).

From Table 1 it may be seen that in all non-pregnant guinea-pigs progesterone levels were low, $7 \mathrm{ng} / \mathrm{ml}$ plasma in ovariectomized animals and 1 to $13 \mathrm{ng} / \mathrm{ml}$ in the normal cycle. (These and other assays have shown that the earlier figure for ovariectomized females given by Heap \& Deanesly (1966) 
was too high, probably owing to the inclusion of recently pregnant animals.) Even with a substantial absorption from implanted progesterone, the plasma levels only increased to $23 \mathrm{ng} / \mathrm{ml}$ and in no instance did the levels reach those in pregnant females, whether normal or ovariectomized.

In ovariectomized, pregnant guinea-pigs with implanted tablets, plasma progesterone concentrations were of the same order as those found in intact animals at a similar stage of pregnancy, and about twenty-fold greater than those in non-pregnant females although in both the average daily absorption of progesterone was about $1.5 \mathrm{mg} /$ day.

These results suggest that in the pregnant guinea-pig there is a significant change in the rate of progesterone metabolism. If it is assumed that the absorption of progesterone from implanted tablets does not vary greatly from day to

TABLE 1

THE EFFECTS OF PREGNANCY AND OF IMPLANTED PROGESTERONE TABLETS ON PLASMA PROGESTERONE LEVELS IN GUINEA-PIGS

\begin{tabular}{|c|c|c|c|}
\hline $\begin{array}{l}\text { Group and No. } \\
\text { of animals }\end{array}$ & $\begin{array}{c}\text { Tablets } \\
(\mathrm{mg})\end{array}$ & $\begin{array}{c}\text { Absorption } \\
(\text { mg/day })\end{array}$ & $\begin{array}{l}\text { Plasma level } \\
(n g / m l)\end{array}$ \\
\hline Normal cyclic (8) & - & - & $9 \quad(1-13)^{*}$ \\
\hline $\begin{array}{l}\text { Normal pregnant } \\
20 \text { to } 25 \text { days }(6) \\
30 \text { to } 35 \text { days (4) }\end{array}$ & - & - & $\begin{array}{l}190(121-317) \dagger \\
266(217-306) \dagger\end{array}$ \\
\hline $\begin{array}{l}\text { Ovariectomized (6) } \\
\text { Ovariectomized (2) } \\
\text { Ovariectomized (4) } \\
\text { Ovariectomized (3) }\end{array}$ & $\begin{array}{l}80 \text { to } 86 \\
173 \text { to } 246 \\
218 \text { to } 302\end{array}$ & $\begin{array}{l}0.5(0.5,0.5) \\
0.5(0.4 \text { to } 0.8) \\
1.7(1.5 \text { to } 1.9)\end{array}$ & $\begin{array}{cc}7 * & \\
7 & (5-9) \\
12 & (7-17) \\
23 & (19-28)\end{array}$ \\
\hline $\begin{array}{l}\text { Ovariectomized pregnant } \\
34 \text { to } 35 \text { days }(5) \\
40 \text { to } 45 \text { days }(4) \\
21 \text { to } 24 \text { days }(6) \\
27 \text { to } 30 \text { days }(5)\end{array}$ & $\begin{array}{c}- \\
\text { - } \\
194 \text { to } 223 \\
195 \text { to } 229\end{array}$ & $\begin{array}{c}- \\
- \\
1.6(1.2 \text { to } 2.2) \\
1.5(1.3 \text { to } 1.8)\end{array}$ & $\begin{array}{lc}75 & (24-119) \dagger \\
138 & (110-191) \dagger \\
433 & (96-988) \\
462 & (91-727)\end{array}$ \\
\hline
\end{tabular}

* Data from Heap, Perry \& Rowlands (1967).

$\dagger$ Data from Heap \& Deanesly (1966).

day, metabolic clearance rate (Tait \& Burstein, 1964) in pregnant females could be less than one-tenth of that in non-pregnant guinea-pigs. Further work is in progress to obtain a more precise estimate by isotope dilution techniques.

These findings may be related to recent observations that transcortin, a corticosteroid-binding globulin found in plasma, has a high affinity for progesterone which at $37^{\circ} \mathrm{C}$ may be bound more strongly than cortisol (Sandberg, Rosenthal, Schneider \& Slaunwhite, 1966; Seal \& Doe, 1966; Gala \& Westphal, 1967). Moreover in the guinea-pig there is a marked rise in the amount of circulating transcortin during pregnancy (Seal \& Doe, 1966; Gala \& Westphal, 1967), which corresponds closely with the rise in plasma progesterone (around Day 20) observed by Heap et al. (1967). It may be assumed from the results that the placenta, and possibly placental oestrogens (Deanesly, 1960), are actively concerned in the change in rate of progesterone metabolism. In some species, but not all, oestrogen administration stimulates the production 
of transcortin (Sandberg et al., 1966; Seal \& Doe, 1966) but, in preliminary experiments, we have found that plasma progesterone levels in spayed females with progesterone tablets have shown no appreciable difference from those in similar females receiving in addition oestradiol or oestrone.

In all normal and hysterectomized females and in males with implanted tablets, plasma progesterone levels have remained low. Other aspects of these experiments will be described elsewhere.

Taken with those of Seal \& Doe (1966), Sandberg et al. (1966) and Gala \& Westphal (1967), the results in Table 1 suggest that in the pregnant guineapig there occurs a marked change in the rate of progesterone metabolism, which may be associated with changes in protein binding.

The work was supported by the Medical Research Council through a personal grant to R.D.

Miss S. C. Hale and Mr R. May are thanked for their technical assistance.

\section{REFERENCES}

DeANesty, R. (1960) Endocrine activity of the early placenta of the guinea-pig. F. Endocr. 21, 235.

DEANESLY, R. (1963) Early embryonic growth and progestagen function in ovariectomized guinea-pigs. 7. Reprod. Fert. 6, 143.

Gala, R. R. \& Westphal, U. (1967) Corticosteroid-binding activity in serum of mouse, rabbit and guinea pig during pregnancy and lactation: possible involvement in the initiation of lactation. Acta endocr., Copenh. 55, 47.

Heap, R. B. (1964) A fluorescence assay of progesterone. F. Endocr. 30, 293.

Heap, R. B. \& Deanesty, R. (1966) Progesterone in systemic blood and placentae of intact and ovariectomized pregnant guinea-pigs. 7. Endocr. 34, 417.

Heap, R. B., Perry, J. S. \& Rowlands, I. W. (1967) Corpus luteum function in the guinea-pig; arterial and luteal progesterone levels, and the effects of hysterectomy and hypophysectomy. 7. Reprod. Fert. 13, 537.

Sandberg, A. A., Rosenthal, H., Schneider, S. L. \& Slaunwhite, W. R., Jr. (1966) Protein-steroid interactions and their role in the transport and metabolism of steroids. In: Steroid Dynamics, p. 1. Ed. G. Pincus, T. Nakao and J. F. Tait. Academic Press, New York.

SEAL, U. S. \& Doe, R. P. (1966) Corticosteroid-binding globulin: biochemistry, physiology and phylogeny. In: Steroid Dynamics, p. 63. Ed. G. Pincus, T. Nakao and J. F. Tait. Academic Press, New York.

TArt, J. F. \& Burstein, S. (1964) In vivo studies of steroid dynamics in man. In: The Hormones, vol. 5, p. 441. Ed. G. Pincus, K. Thimann and E. B. Astwood. Academic Press, New York. 